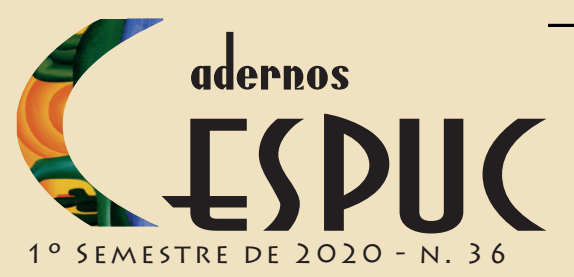

\title{
INTERSEÇÕES: O DARWINISMO SOCIAL EM RUBENS FIGUEIREDO E O HUMANITISMO MACHADIANO*
}

\author{
Rejane Fernández Loureiro de Paiva*
}

\begin{abstract}
Resumo
Este artigo trata da interlocução que o romance Passageiro do fim do dia (2010), de Rubens Figueiredo, estabelece com o Humanitismo, a filosofia cínica proposta por Quincas Borba, notória personagem de Machado de Assis. Apesar da distância de aproximadamente 150 anos que separa os dois autores, entendemos que o darwinismo social, sobre o qual se detém Rubens Figueiredo, e o humanitismo machadiano, conformam-se como estratégias textuais similares. Ambos os autores interpelam correntes filosóficas positivistas, em voga na época do "bruxo do Cosme Velho" e ainda vigentes, mormente no que se aplica ao postulado de Charles Darwin aplicado ao mundo social, nos anos atuais. Assim, ambos tematizam as relações de força, em que prevalecem o ganho, o prestígio pessoal e a soberania do interesse. Enquanto Machado de Assis se centra nos jogos de salão da Corte, Rubens Figueiredo privilegia a arraia miúda, a classe trabalhadora e as interdições que lhes são impostas. Encontramos, tanto na narrativa de Rubens Figueiredo, quanto na obra de Machado de Assis, uma busca por uma "teoria de tudo", "uma doutrina que, segundo diziam, abria mil caminhos, explicava muita coisa e de uma vez por todas", no universo ficcional do primeiro, e, na linguagem de Machado de Assis, "a mais abrangente das filosofias, a ponto de vir a ser mesmo uma nova religião", o "remate das coisas". Todos esses elementos conformar-se-iam como a busca impossível por uma resposta radical, totalizante, que aliviasse os males humanos, encenados em suas narrativas.
\end{abstract}

Palavras-chave: Darwinismo social. Humanitismo. Interações sociais. Teorias positivistas. Crítica social.

\section{INTERSECCIONES: EL DARWINISMO SOCIAL EN RUBENS FIGUEIREDO Y EL HUMANISMO MACHADIANO}

Résumen

Este artículo trata de la interlocución que la novela establece con el Humanitismo, la filosofía cínica propuesta por Quincas borba, notoria personaje de Machado de Assis. En que pese la distancia de cerca de 150 años, que separa a los dos autores, se entiende que el darwinismo social, en el cual se detiene Rubens Figueiredo, y el humanitismo de Machado, se conforman como estrategias textuales semejantes. Ambos los autores interpelan corrientes filosóficas positivistas, en curso en la época del "brujo de Cosme Velho" y todavía vigentes, principalmente en lo que se aplica al postulado de Charles Darwin, aplicado al mundo social, en los años actuales. Así, ambos tienen por tema las relaciones de fuerza, en que prevalecen la ganancia, el prestigio personal y la soberanía del interese. Mientras Machado de Assis se centra en los juegos de salón de la Corte, Rubens Figueiredo privilegia la franja más pobre de la población, y las interdicciones que le son impuestas. Encontramos, tanto en la narrativa de Rubens Figueiredo, cuanto en la obra de Machado de Assis, una búsqueda por la "teoría de todo", "una doctrina que, según decían, abría mil caminos, explicaba mucha cosa y de una vez por todas", en el universo ficcional del primero y, en el lenguaje de Machado de Assis, "la más abarcadora de las filosofías", a punto de venir a ser, aún, una nueva religión", "el remate de las cosas". Todos esos elementos se conformarían como la búsqueda imposible por una respuesta radical, totalizante, que aliviara los males humanos, escenificados en sus narrativas.

Palabras-clave: Darwinismo social. Humanitismo. Interactuaciones sociales. Teorías positivistas. Crítica social.

Recebido em 21/05/2020

Aceito em 13/07/2020

* Este trabalho é parte de tese de doutoramento Subjetividades em trânsito: deslocamentos do sujeito em Rubens Figueiredo.

"Doutora em Letras pelo Programa de Pós-Graduação em Letras - Literaturas de Língua Portuguesa -, da Pontifícia Universidade Católica de Minas Gerais. Mestre em Teoria da Literatura pelo Programa de Pós-Graduação da Faculdade de Letras da UFMG. ORCID: 0000-0001-9542-3214.. 


\section{Interseções: Rubens Figueiredo e o Humanitismo Machadiano}

O século XIX viu surgir um grande número de teorias: a evolucionista, de Darwin; a positivista de Comte; a marxista, de Karl Marx, e a psicanalítica, de Freud, dentre outras. Essas teorias, controversas muitas vezes, ainda hoje no século XXI, sustentam a base do pensamento ocidental e se encontram no centro de muitas discussões. No que toca ao universo artístico, acreditamos que não há como o intelectual furtar-se a tais ocorrências, seja para reforçá-las, perquiri-las ou refutá-las (Cf. Bakhtin, 1988). Nessa perspectiva, valemo-nos de Roberto Schwarz, que, na análise da articulação entre forma literária e processo social no Brasil, afirma que

[...] ao contrário do que geralmente se pensa, a matéria do artista mostra assim não ser informe: é historicamente formada, e registra de algum modo o processo social a que deve a sua existência. Ao formá-la, por sua vez, o escritor sobrepõe uma forma a outra forma, e é da felicidade desta operação, desta relação com a matéria pré-formada - em que imprevisível dormita a História - que vão depender profundidade, força, complexidade dos resultados. (SCHWARZ, 1981, p.25).

Nesse sentido, cumpre retomar as proposições de Bakhtin, no que diz respeito à pluralidade de vozes no gênero romanesco. O filósofo ressalta o hibridismo do romance, que se conforma como um sistema de fusão de línguas literariamente organizado, cujo objetivo é aclarar uma linguagem com a ajuda de outra. O argumento do gênero romance, de acordo com Bakhtin, serve para a representação dos sujeitos falantes e de seus universos ideológicos, assim como serve para desmascarar as linguagens sociais e as ideologias que nelas se encontram. Bakhtin postula que é no processo de formação ideológica do homem que o objetivo da assimilação da palavra de outrem adquire uma significação ainda mais profunda e mais importante. Ademais, ela procura definir as próprias bases de nossa atitude ideológica em relação ao mundo, assim como busca moldar nosso comportamento. O estudioso subdivide a palavra alheia em "palavra autoritária" - entendida como possuidora de uma linguagem hierática, que reconhecemos e assimilamos, tais como o discurso dogmático da religião, da ciência, etc. -, e "palavra interiormente persuasiva" - palavra ideológica do outro, que se junge estreitamente com a "nossa palavra" (BAKHTIN, 1988, p.145). Ambas as categorias se combinam e conformam um amálgama químico no contexto do discurso.

Desse modo, observamos que o romance Passageiro do fim do dia (FIGUEIREDO, 2010) põe à prova a palavra autoritária da Ciência tradicional, na medida em que problematiza o discurso cientificista que tem, por princípio básico, a teoria da evolução proposta por Charles Darwin, sobretudo aplicada ao tecido social. Vale lembrar que o darwinismo social acredita na premissa da existência de sociedades superiores a outras, o que explicaria o motivo pelo qual determinados indivíduos sucumbem na escala social, enquanto outros prosperam. Seriam estes últimos, portanto, os mais aptos, os adaptados. Esse conceito, de alguma forma, justificaria políticas que não fazem distinção entre aqueles que não são capazes de se sustentar e aqueles autossuficientes. Assim entendida, essa temática pode ser observada na imagem nuclear da trama de Rubens Figueiredo, a mútua caçada empreendida pela vespa Pepsis e a aranha Lycosa, 


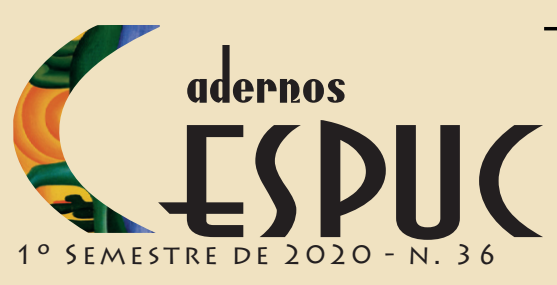

\section{Rejame Fermānadez Loureiro de Paiva}

figurada no cenário da cidade, que representaria, por sua vez, a própria interação do elemento humano, regida pelas leis selvagens da força do mercado, sobretudo nos grandes centros urbanos.

Em Passageiro do fim do dia (FIGUEIREDO, 2010), o protagonista Pedro embarca em um ônibus a caminho do Tirol, bairro periférico onde mora a namorada Rosane. A personagem leva consigo um livro, que trata da viagem do cientista Charles Darwin pelo país, e leva, também, um radinho de pilha, em que ouve as notícias do mercado econômico. Ao longo da incômoda travessia, Pedro rememora as histórias que lhe foram contadas pela namorada a respeito da vida no bairro pobre, e observa, atentamente, os companheiros de jornada.

O darwinismo insere-se na trama de Rubens Figueiredo através do livro sobre Darwin que Pedro lê, em que se observa a luta entre a vespa e a aranha, já referida. Por duas vezes o protagonista tomara o exemplar em suas mãos, conseguindo finalmente lê-lo quando um juiz, cliente do sebo de propriedade de Pedro, destaca-o do restante do acervo e ressalta suas "qualidades". Desse modo, ao acionar as ideias do naturalista inglês e contrapô-las à paisagem humana encenada nas rotineiras viagens da personagem Pedro, o autor estabelece um diálogo com o discurso da Ciência do século XIX, conformando-o como uma janela discursiva que se abre na obra. Cumpre observar que o livro que Pedro lê, por fazer parte do cabedal de um sebo, já passou por muitas leituras e por muitos leitores.

Ao conceber seu protagonista como um alfarrabista, o autor, de imediato, desenha uma relação com a história da literatura universal. A personagem Pedro é, acima de tudo, concebida como um leitor, mas não um leitor passivo, "distraído". Longe disso, Pedro interpela o texto que lê com sagacidade, como se pode observar na passagem em que Darwin, sempre recriado por Rubens Figueiredo, não consegue fazer-se entender pelo barqueiro, supondo-o "um negro de todo imbecil" (FIGUEIREDO, 2010, p.66): "Por imaginar que o homem talvez fosse surdo, ou apenas por se perturbar com uma irritação crescente, causada por seus esforços frustrados, Darwin passou a falar cada vez mais alto, ao explicar o que queria saber. (Mas como assim? Será que falava em inglês com o escravo? - pensou Pedro)" (FIGUEIREDO, 2010, p.66).

Desse modo, a marcante presença do darwinismo, que se configura como temática nuclear da trama, nos proporciona abrir outra janela na obra em questão: um possível diálogo entre Rubens Figueiredo e Machado de Assis, o que viria, por sua vez, a inserir o escritor fluminense contemporâneo na história literária brasileira. Assim, guardadas as devidas diferenças - em que se destaca o hiato de mais de um século entre suas publicações -, buscamos ressaltar, aqui, a provável interlocução entre os textos de Rubens Figueiredo e Machado de Assis, já que ambos interpelam correntes filosóficas positivistas, em voga na época do "bruxo do Cosme Velho" e ainda vigentes, mormente no que se aplica ao postulado de Charles Darwin aplicado à vida social.

Rubens Figueiredo evidencia, em entrevista a Paulo Roberto Tonani do Patrocínio (2016), o uso da teoria evolucionista para justificar explorações tais como a escravista e a colonialista, em um primeiro momento e, depois, a exploração nas relações de trabalho, sobretudo na parcela mais desqualificada dos trabalhadores. Por esse modo, o escritor fluminense busca discutir, em alguma medida, o papel da Ciência num contexto de relações de poder assimétricas, uma vez 
que a simples suposição de uma superioridade e de seu contrário atua como força mantenedora do regime de desigualdade. Em Machado, encontramos essa abordagem de maneira muito específica em seu "Humanitismo", a filosofia cínica fundada por Quincas Borba, notável personagem do romance homônimo, editado em 1891, obra em que o autor põe em questão, igualmente, a política imperial e os impasses da Coroa diante da reforma da escravidão. Nas palavras de Luiz Carlos Junqueira Maciel, em "Nada e a nossa condição", "Quincas Borba e suas teorias é (sic) uma caricatura ou paródia do Absolutismo, tanto em termos políticos quanto em termos científicos, uma vez que as teorias darwinistas, evolucionistas e positivistas são questionadas por Machado de Assis" (MACIEL, 2006, p.21). A isso se acrescente a observação da historiadora social Laila Correa e Silva (2017), ao afirmar que, no caso do discurso filosófico construído por Machado de Assis - o "Humanitismo" borbiano -, buscava-se refletir sobre a maneira como as teorias científicas e filosóficas, populares no Brasil a partir do final da década de 1870, tinham a capacidade de construir um discurso superficial e, ao mesmo tempo, perigoso, para sustentar hierarquias e desigualdades sociais.

A doutrina machadiana do "Humanitismo"aparece, também, em Memórias Póstumas de Brás Cubas, publicado em 1881. Em nossa análise, portanto, faremos um recorte na extensa obra do autor, detendo-nos nos dois romances referidos, a fim de destacar os pontos de interseção com a obra de Rubens Figueiredo. Encontramos como ponto comum das obras de Machado de Assis, objeto deste texto, e a obra de Rubens Figueiredo, uma aguda crítica à sociedade de seu tempo, por meio da retomada de correntes teórico-científicas do século XIX. Nesse sentido, entendemos que o humanitismo machadiano e o darwinismo no qual se detém Rubens Figueiredo conformam-se como estratégias textuais comuns.

Ao se considerar que, à época de Machado de Assis já se questionavam as teorias que preconizavam, das mais variadas formas, a imposição dos "fortes" sobre os mais "fracos", pensamos encontrar uma aproximação fulcral entre esse escritor e Rubens Figueiredo. Essa proximidade se centra no fato de haver, na escrita de ambos os autores, uma busca por uma "teoria de tudo", "uma doutrina que, segundo diziam, abria mil caminhos, explicava muita coisa e de uma vez por todas" (FIGUEIREDO, 2010, p.122), a "lógica das coisas", no universo ficcional de Rubens Figueiredo; na linguagem de Machado de Assis, "a mais abrangente das filosofias, a ponto de vir a ser mesmo uma nova religião", o "remate das coisas", em que se almeja, também, descobrir um "medicamento sublime", um "emplasto anti-hipocondríaco, destinado a aliviar a nossa melancólica Humanidade” (ASSIS, 1978, p.27). Todos esses elementos conformar-se-iam como a busca impossível por uma resposta radical, totalizante, que explicasse ou solucionasse, de uma só penada, os males humanos, agrupados nas dissensões sociais.

Em seu delírio, Quincas Borba entende o "Humanitismo" como o princípio de tudo e, paradoxalmente, o nada, a grande síntese, a teoria destinada a ser a mais abrangente das filosofias, a ponto de vir a ser mesmo uma nova religião. Aqui, essa teoria criada por Machado de Assis se aproxima bastante do positivismo de Auguste Comte, doutrina filosófica que seria de culto ao saber racional e científico, que se atribuía foros de uma religião às avessas. Essa crença, em que a razão se sobrepõe aos sentimentos, viria a substituir, inclusive, o cristianismo; 
no momento em que a Ciência é o verdadeiro saber, há sempre postulados racionais, lógicos e científicos para explicar a vida. Na esfera literária, observe-se que a personagem Quincas Borba, autora de uma "Nova igreja", é oriunda de Barbacena, antigo "Arraial da Igreja Nova", sede reconhecida de um sanatório para alienados, o que bem demonstra o quanto a escrita de Machado de Assis é intrincada. Note-se que a própria loucura - refúgio último de Quincas Borba - conformar-se-ia como um dos estigmas da degeneração, proposto pela teoria do darwinismo social, segundo aponta Lilia Schwarcz (2017).

A respeito da interlocução entre o Humanitismo de Machado de Assis e as ideologias positivistas, Roberto Gomes, em "O alienista: loucura, poder e ciência” (1993), afirma:

No entanto, mesmo no momento de crítica radical, Machado não se coloca na mesma linha de tiro de seus alvos. Ele não desespera da ciência enquanto conhecimento, resultado, investigação. Nem a razão lhe parece um mal. O que Machado mira, por detrás da hipocrisia humanitária do positivismo, da sede de esgotar as razões do universo e da vida humana, é a insânia do exercício de poder inerente à concepção de conhecimento (e ao tipo de fundamentação do conhecimento), que a razão e a ciência positivistas enaltecem. $\mathrm{O}$ alvo em mira é o poder, essa coisa escorregadia, que não diz seu nome, que gera as mil máscaras por atrás das quais se esconde. (GOMES, 1993, p.153).

É com um refinado humor que Machado de Assis trata os paradoxos da Ciência, assim apropriada, haja vista os princípios da doutrina que cria, que podemos observar na exemplificação de Quincas Borba sobre o que viria a ser "Humanitas". O filósofo machadiano narra, então, a morte de sua avó: porque o cocheiro precisava comer, instigado pelo "Humanitas" que nele habitava, fustigou o cavalo, que por sua vez ultrapassou um obstáculo. Acontece que esse entrave era a avó de Quincas Borba. No entanto, de acordo com os dogmas dessa doutrina, poderia ser também um "rato ou um cão, é certo que minha avó não morreria, mas o fato era o mesmo: Humanitas precisa comer" (ASSIS, 2009, p.57). Cumpre que o médico que atendia a Quincas Borba, na encenação de Machado de Assis, desprovido de fé em doutrinas, pondera: “mas filosofia é uma coisa, e morrer de verdade é outra; adeus" (ASSIS, 2009, p.54).

Essa passagem de Quincas Borba nos remete, de imediato, a certa imagem criada por Rubens Figueiredo em Passageiro do fim do dia. Trata-se do momento em que a polícia montada investe sobre vendedores ambulantes, que "corriam aos empurrões, em atropelo e em fuga pela rua, enquanto olhavam para os lados e para trás, por cima do ombro, entre gritos e estampidos cada vez mais próximos e mais violentos que vinham de várias direções" (FIGUEIREDO, 2010, p.15). E, ao atingir o protagonista: "O alerta, a dor propriamente dita, só veio quando o cavalo - o mesmo cavalo, com os dentes à mostra e a gengiva roxa, brilhante - arremeteu num curto galope contra as pessoas revoltadas e, de passagem, pisoteou a parte de baixo da perna de Pedro" (FIGUEIREDO, 2010, p.28). Assim, nas duas cenas destacadas, é notória a preponderância do forte sobre o fraco, que não tem "onde entrar nem para onde fugir” (FIGUEIREDO, 2010, p.19). Essas encenações expressam a visada crítica de ambos os autores à banalização dessa mesma condição, sempre justificada pelo determinismo social. Ficam patentes, por conseguinte, a preponderância da razão sobre o sentimento, assim como a crueldade desses princípios, em que não há lugar para o sofrimento ou para a dor. 
Dessa forma, "Humanitas", conceito principal do Humanitismo, conformar-se-ia como o princípio universal e indestrutível da vida, substância recôndita e idêntica, presente em todas as coisas e que nem a morte extingue. Nessa perspectiva, tudo o que é vivo igualar-se-ia e não haveria distinção, portanto, entre um cão ou um ser humano, entre a morte de uma pessoa próxima ou a de um anônimo, já que a finitude é entendida como algo inerente ao que está vivo. Percebida como algo natural, não há lugar para o sofrimento, e essa finitude deve ser racionalizada, numa perspectiva científica generalista e universal, que, por sua vez, elimina a individualidade e a especificidade. Os indivíduos, segundo o filósofo machadiano, são apenas "bolhas transitórias" (ASSIS, 2006: 23), que aparecem ou se finam ao sabor da fervura.

A essa máxima sumamente cínica (e cruel, diga-se de passagem) de Quincas Borba, "bolha não tem opinião", podemos fazer soar a voz de Rubens Figueiredo na figuração de Rosane que assinala o sofrimento da colega, ao narrar como havia perdido emprego, casa e móveis:

percebia como a colega ficava comovida, via que naquela comoção já nem havia mais revolta, nem a memória da revolta, nem sequer um desejo de revolta incompreendido. Falava em voz baixa: não a voz de quem protesta, se lamenta, mas de quem pergunta para si mesma - a voz de quem cansou, já queimou até as cinzas e só quer entender como é possível. (FIGUEIREDO, 2010, p.153-154).

Por ocasião da lesão em seu pulso, motivada pela intensa repetição de movimentos, na fábrica, Rosane busca a médica da empresa, que lhe dá apenas um dia de afastamento. Ao retornar ao trabalho, no dia seguinte, a personagem tem que sufocar a dor que sente:

No dia seguinte, diante da esteira de metal em movimento, Rosane mal tentou segurar um copinho de plástico e logo ele caiu da sua mão. Soltou um grito curto, chorou sem barulho, o pulso encolhido no meio do peito, os ombros curvados para a frente. Preso dentro da boca, um outro gemido subiu e demorou a terminar. (FIGUEIREDO, 2010, p.155).

Também o pai de Rosane, nas invariáveis idas à perícia médica, ficava na sala de espera com muitos outros como ele, ouvindo o "silêncio dos estropiados" (FIGUEIREDO, 2010, p.104). Eram ocasiões tensas, em que, muitas vezes, os médicos se negavam a prorrogar as licenças trabalhistas, para desespero daquela multidão de homens e mulheres. No entanto, não havia a quem recorrer, ninguém se ocuparia de suas causas, suas vozes não seriam ouvidas. Do mesmo modo, o outro paciente, companheiro de Pedro na enfermaria, homem "magrinho, de voz fraca", gemia "com voz fina de criança, no tom sincero de quem sabe que não pode ser ouvido por ninguém” (FIGUEIREDO, 2010:70). Rosane, por sua vez, ao explicar para Pedro as mudanças vertiginosas em seu bairro, pondera:

Contra o fundo da sua memória de criança e de adolescente, aquela transformação, já consumada e sem volta, se apresentava como um processo rápido demais, fácil demais, para que fosse possível ter acontecido assim - sem resistência, sem alternativa. E isso ela não conseguia explicar: era preciso engolir e pronto - essa era a ideia que estava no ar - era o próprio ar. (FIGUEIREDO, 2010, p. 53. Grifo nosso). 


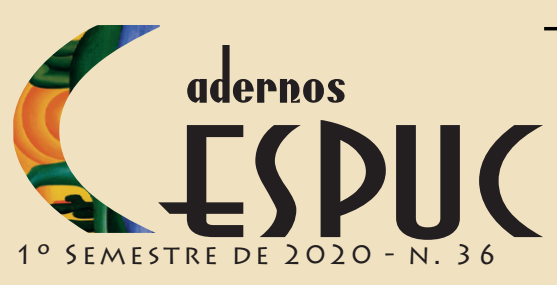

\title{
Rejame Fermānadez Loureiro de Paiva
}

Sob a perspectiva da violência do sistema pelo qual se organiza a sociedade, a "Igreja Nova", como a pretende Quincas Borba, justifica-se pela negação do próprio homem e ratifica a ideia de sua coisificação. De acordo com seus pressupostos, em uma situação de guerra, o vencido não importa, ele desaparece em prol da manutenção do princípio vital. Vida ou morte, vitória ou derrota: tudo obedece sempre a um mesmo preceito. Até mesmo o que é considerado como uma grande catástrofe é movido por leis universais, que objetivam a continuação da vida, a perpetuação e a evolução da espécie humana. Torna-se, portanto, necessário e benéfico, de acordo com as elucubrações de Quincas Borba:

\begin{abstract}
Aparentemente, há nada mais contristador que uma dessas terríveis pestes que devastam um ponto do globo? E, todavia, esse suposto mal é um benefício, não só porque elimina os organismos fracos, incapazes de resistência, como porque dá lugar à observação, à descoberta da droga curativa. A higiene é filha de podridões seculares; devemo-la a milhões de corrompidos e infectos. Nada se perde, tudo é ganho. (ASSIS, 2006, p.23).
\end{abstract}

Além da atribuição de uma funcionalidade sanitária aos grandes males que afligem a humanidade, essa última frase parece retomar a máxima de Lavoisier, "na natureza nada se cria, nada se perde, tudo se transforma". Observemos, no entanto, no excerto, a ambiguidade da palavra "ganho", que remete, de imediato, à linguagem de mercado, em conformidade com a temática da ambição sem ética percebida na obra.

Desse modo, todo o encadeamento das ações nesse romance de Machado de Assis parece corroborar a ideologia de Quincas Borba, em que alguém sempre lucra com o prejuízo alheio. Assim, é necessário que a irmã de Rubião morra para que ele receba a herança do filósofo de Barbacena. É igualmente necessário que Rubião decaia para que Palha e Sofia ascendam; é forçoso, ainda, haver uma epidemia nas Alagoas para que Maria Benedita se case com Carlos Maria e para que Sofia, por sua vez, suba mais um degrau em sua escalada social. É preciso, também, que a choça da mulher paupérrima se incendeie para que o bêbado acenda o seu charuto, assim como é imprescindível a cadeia alimentar: "este frango, que eu almocei agora mesmo, é o resultado de uma multidão de esforços e lutas, executados com o único fim de dar mate ao meu apetite" (ASSIS, 1978, p.165), conforme esclarece Quincas Borba ao amigo Brás Cubas.

Importa salientar que o primeiro elo a sucumbir nessa imensa cadeia de acontecimentos que estrutura o romance de Machado de Assis é a mana "Piedade". É ela, sobretudo, a primeira a ser sacrificada a fim de que "Humanitas" sobreviva, e bem, e à larga, para que os mais fortes permaneçam. "As catástrofes são úteis, e até necessárias", comenta o irônico narrador de Quincas Borba (ASSIS, 2009, p.202).

Esses preceitos do Humanitismo machadiano nos remetem àquela espécie de "pedágio da evolução" que o protagonista de Rubens Figueiredo pensa ser necessário pagar, ao observar as pessoas na fila de ônibus, sob um sol causticante: "[...] é preciso reconhecer: sem mal-estar, sem adversidade, sem um castigo sequer, como se pode esperar que haja alguma adaptação? (FIGUEIREDO, 2010, p.8). 
Emblemática para síntese dessa ideia é a explicação do campo de batatas, no romance de Machado de Assis:

Supõe tu um campo de batatas e duas tribos famintas. As batatas apenas chegam para alimentar uma das tribos, que assim adquire forças para transpor a montanha e ir à outra vertente, onde há batatas em abundância; mas, se as duas tribos dividirem em paz as batatas do campo, não chegam a nutrir-se suficientemente e morrem de inanição. A paz, nesse caso, é a destruição; a guerra é a conservação. Uma das tribos extermina a outra e recolhe os despojos. Daí a alegria da vitória, os hinos, aclamações, recompensas públicas e todos os demais efeitos das ações bélicas. Se a guerra não fosse isso, tais demonstrações não chegariam a dar-se, pelo motivo real de que o homem só comemora e ama o que lhe é aprazível ou vantajoso, e pelo motivo racional de que nenhuma pessoa canoniza uma ação que virtualmente a destrói. Ao vencido, ódio ou compaixão; ao vencedor, as batatas. (ASSIS, 2009, p.58-59).

Dessa forma, de acordo com a ideologia de Quincas Borba, numa disputa por alimentos, por exemplo, a divisão equitativa da comida faria com que esta fosse insuficiente para saciar devidamente a todos, mas, se há guerra, os vitoriosos terão comida bastante para se nutrirem e se fortalecerem ainda mais.

O que convém sublinhar, desde já, é que "Humanitas", esse princípio único, que anima a todos e a tudo, não o faz de maneira igualitária, ratificando, assim, a visão de uma sociedade dividida em diferentes camadas, nas quais se pode ascender atendendo à "grande lei do valor pessoal" (ASSIS, 1978:162), que hoje podemos chamar de "meritocracia”, princípio que não atenta para a desproporção das oportunidades. Quincas Borba explica as leis internas da sua doutrina, segundo a narração de Brás Cubas:

Como me não aparecesse assaz clara esta exposição, Quincas Borba desenvolveu-a de um modo profundo, fazendo notar as grandes linhas do sistema. Explicou-me que, por um lado, o Humanitismo ligava-se ao bramanismo, a saber, na distribuição dos homens pelas diferentes partes do corpo de Humanitas; mas aquilo que na religião indiana tinha apenas uma estreita significação teológica e política, era no Humanitismo a grande lei do valor pessoal. Assim, descender do peito ou dos rins de Humanitas, isto é, ser um forte, não era o mesmo que descender dos cabelos ou da ponta do nariz. Daí a necessidade de cultivar e temperar o músculo. Hércules não foi senão um símbolo antecipado do Humanitismo. Neste ponto Quincas Borba ponderou que o paganismo poderia ter chegado à verdade, se se não houvesse amesquinhado com a parte galante dos seus mitos. Nada disso acontecerá com o Humanitismo. Nessa igreja nova não há aventuras fáceis, nem quedas, nem tristezas, nem alegrias pueris. O amor, por exemplo, é um sacerdócio, a reprodução um ritual. Como a vida é o maior benefício do universo, e não há mendigo que não prefira a miséria à morte (o que é um delicioso influxo de Humanitas), segue-se que a transmissão da vida, longe de ser uma ocasião de galanteios, é a hora suprema da missa espiritual. Porquanto, verdadeiramente, há só uma desgraça: é não nascer. (ASSIS, 1978, p.163-164).

Cumpre lembrar que ainda hoje, na zona rural indiana, o sistema de classes permanece. Machado de Assis ressalta o absurdo dessa "Nova Igreja" com o estranhamento da personagem Brás Cubas, a quem "a clareza da exposição, a lógica dos princípios, o rigor das consequências", de seu criador, lhe parecia "superiormente grande" (ASSIS, 1978, p.164). Essa passagem do 
texto machadiano nos remete, novamente, à narrativa de Rubens Figueiredo, no momento em que uma jovem magistrada propõe, ironicamente, uma nova ordem social, em que loucos, ladrões, assassinos e fraudadores andassem livres pelas ruas. É com um "ar sensato", uma "cadência justa da voz", que a juíza conclui que a humanidade passaria, assim, para "[u]m novo patamar de civilização” (FIGUEIREDO, 2010, p.128).

As linhas do Humanitismo, concebido com um "formidável rigor de lógica", seguem sendo traçadas pela voz da personagem Quincas Borba:

\begin{abstract}
Reorganizada a sociedade pelo método dele, nem por isso ficavam eliminadas a guerra, a insurreição, o simples murro, a facada anônima, a miséria, a fome, as doenças; mas sendo esses supostos flagelos verdadeiros equívocos do entendimento, porque não passariam de movimentos externos da subsistência interior, destinados a não influir sobre o homem, senão como simples quebra da monotonia universal, claro estava que a sua existência não impediria a felicidade humana. (ASSIS, 1978, p.165-166).
\end{abstract}

Emana do texto de Machado de Assis uma ironia tão fina que não há como não voltar a leitura uma e mais vezes. Aqui, não há desgraça, tudo obedece a uma ordem preestabelecida e qualquer desarranjo aparente, "verdadeiro equívoco do entendimento", deve ser visto com as lentes coloridas de Pangloss, notável personagem de Voltaire (1759), um otimista que sempre repetia "tudo vai pelo melhor no melhor dos mundos possíveis". No entanto, o broche de ouro dessa obra de Voltaire é a frase em que se lê que "devemos é cultivar o nosso jardim", ou seja, cada um que cuide de si.

Há de se notar que, no romance Quincas Borba (2009), as personagens parecem encarnar, elas mesmas, os princípios da doutrina criada pelo filósofo machadiano, sendo, "ao mesmo tempo veículo, cocheiro e passageiro" de "Humanitas". Desse modo, Carlos Maria é presunçoso e ególatra, pois acreditava ser a encarnação de um "deus grande e amigo" (ASSIS, 2009, p.264). Por sua vez, é Sofia, a dona de uma inveja, um "despeito" monumental, no tocante ao casamento de Carlos Maria e Maria Benedita. Assim, o indivíduo que "estripa" o outro, em uma clara demonstração de força, nada mais é que o próprio Palha, ao exaurir Rubião de todos os seus bens e abandoná-lo à própria sorte. Essas "leis" podem ser conferidas no fragmento que segue:

Nota que eu não faço do homem um simples veículo de Humanitas; não, ele é ao mesmo tempo veículo, cocheiro e passageiro, ele é o próprio Humanitas reduzido; daí a necessidade de adorar-se a si próprio. Queres uma prova da superioridade de meu sistema? Contempla a inveja. Não há moralista grego ou turco, cristão ou muçulmano, que não troveje contra o sentimento da inveja. O acordo é universal, desde os campos da Induméia até o alto da Tijuca. Ora bem; abre mão dos velhos preconceitos, esquece as retóricas rafadas, e estuda a inveja, esse sentimento tão sutil e tão nobre. Sendo cada homem uma redução de Humanitas, é claro que nenhum homem é fundamentalmente oposto a outro homem, quaisquer que sejam as aparências contrárias. Assim, por exemplo, o algoz que executa o condenado pode excitar o vão clamor dos poetas; mas substancialmente é Humanitas que corrige em Humanitas uma infração da lei de Humanitas. O mesmo direi do indivíduo que estripa a outro; é uma manifestação da força de Humanitas. Nada obsta (e há exemplos) que ele seja igualmente estripado. Se entendeste bem, facilmente compreenderás que a inveja não é senão uma 
admiração que luta, e sendo a luta a grande função do gênero humano, todos os sentimentos belicosos, são os mais adequados à sua felicidade. Daí vem que a inveja é uma virtude. (ASSIS, 1978, p.164).

Sobressai, no excerto acima, a repetição enfática da palavra "Humanitas" que, ao mesmo tempo em que reforça a teoria defendida, a desloca. De qualquer modo, a se considerarem essas regras, assim dispostas, é melhor observar a máxima do narrador de Quincas Borba, que conclui: "Tão certo é que a paisagem depende do ponto de vista, e que o melhor modo de apreciar o chicote é ter-lhe o cabo na mão" (ASSIS, 2009:72). Essa mudança de perspectiva fica patente na figuração do diretor de banco, que se humilha a ponto de causar vergonha a si próprio, diante de um ministro e, encontrando em Palha certa inferioridade, trata-o com arrogância:

O diretor fez-se então severo, superior, frio, poucas palavras; chegou a arregaçar com desdém a venta esquerda, a propósito de uma ideia do Palha, que a recolheu logo, concordando que era absurda. Copiou do ministro o gesto lento. Saindo, não foram dele as cortesias, mas do dono da casa. (ASSIS, 2009, p.172).

Chama a atenção, no fragmento acima, o uso da locução "fez-se, então, severo, superior, frio", que indica que esses traços de personalidade não eram características permanentes do diretor de banco. Do mesmo modo, o verbo "copiar" explicita a imitação do comportamento do outro, que julga superior a si. Os sentimentos controversos que essas sucessivas mudanças de comportamento provocam na personagem são descritos pelo narrador, primeiro na visita que o diretor de banco faz ao ministro e, depois, a Palha: "Enterrou o chapéu e saiu. Saiu humilhado, vexado de si mesmo. Não era o negócio que o afligia, mas os cumprimentos que fez, as desculpas que pediu, as atitudes subalternas um rosário de atos sem proveito" (ASSIS, 2009, p. 172). E, sob outra perspectiva, ao sair da casa do Palha: "Em dez minutos tinha a alma espantada e restituída a si mesma, tais foram as mesuras do dono da casa, os apoiados de cabeça, e um raio de sorriso perene, não contando oferecimentos de chás e charutos" (ASSIS, 2009, p. 172).

O gestual do desdém não escapou a Rubens Figueiredo na construção de relações entre suas personagens, conforme podemos observar na interação do ex-juiz com jovens advogados, quando se encontra no sebo de Pedro, folheando velhos livros:

Quando um advogado de terno e gravata ou uma advogada de tailleur se aproximava e the fazia uma pergunta, ou apenas o cumprimentava, ele, que sempre vestia calça de vinco bem marcado e uma camisa de manga curta abotoada até o último botão, com o colarinho estrangulado na raiz do pomo de adão palpitante, por trás da pele mole e rugosa do pescoço ele, o juiz, o ex-juiz, o ex-professor emérito, demorava a desgrudar os olhos do papel e voltarse para o conhecido ou a conhecida que tinha falado com ele. (FIGUEIREDO, 2010, p.123).

Observa-se, na construção do aspecto físico dessa personagem, certo tom de escárnio, que escapa na escolha dos adjetivos, "mole" e "rugosa", aplicados à pele do pescoço "estrangulado" pelos botões da camisa. Tal como em Machado de Assis, o narrador de Rubens Figueiredo descreve a postura igualmente cambiante do juiz: 
Estipulava uma quantia mensal para a esposa gastar com a casa e os filhos, sentia-se no direito de ficar furioso quando aquele valor era ultrapassado e gostava de mostrar para os amigos como era rigoroso no seu regime doméstico. Ao mesmo tempo sempre emprestava dinheiro aos amigos, sobretudo para aqueles que não lhe pagavam.

Nem por isso o juiz ficava menos amigo deles. Ao contrário, quanto mais os amigos, em suas conversas, sempre em linguagem estudada e paliativa, confidenciavam entre si suas falhas de caráter - quanto mais conversavam sobre as manifestações de suas espertezas, sobre seus atos de desonestidade e de egoísmo predador, sempre num tom de dignidade ferida e de consciência injustiçada -, quanto mais faziam isso, mais amigos se tornavam. Entre eles, ser amigo era aquilo, acima de tudo. Amizade era um jeito de falar e ouvir aquelas coisas, um jeito capaz de tomar para si e redistribuir numa permuta, entre todos eles, toda a razão, todo o mérito e não deixar para os outros senão as sobras, os ossos roídos. (FIGUEIREDO, 2010, p.129-130).

Apesar de distantes no tempo, esse ponto de tangência nas escritas de Machado de Assis e Rubens Figueiredo dá mostras de que bem pouca coisa mudou na estruturação social, ao longo dos anos. Ambos os autores encenam a coreografia própria das relações de poder, em que as partes fazem uso da arrogância ou da subserviência, a depender da posição que ocupam momentaneamente, corroborando, ademais, o pragmatismo e o cálculo que permeiam tais ligações. Na narrativa do escritor contemporâneo, o cenário é o de um campo de batalha, figurado nas imagens da aranha e da vespa, que estão, reiteradamente, cingindo as diferentes situações encenadas no romance. De um lado, uma multidão de homens, mulheres e crianças que, maltrapilhos, acenam com suas doenças, feridas e mutilações e, de outro, poucos indivíduos usufruindo de muitos benefícios. Numa sociedade estruturada pelo valor do capital, fica bem difícil, se não impossível, a negociação social, quando não se possui moeda de troca. Restalhes, então, silenciar e, quando muito, suplicar, como fizeram os pais de Rosane. Ou, então, responder com violência à violência com que são tratados

Assim, é interessante observar o vínculo claro da teoria construída por Machado de Assis com os preceitos de Darwin, em que está expressa a ideia de que somente os mais fortes e aptos sobrevivem. Afinal, em uma luta de cães, que também poderia ser de homens, "leva o osso o que for mais forte" (ASSIS, 2009:185). De igual maneira, reiteramos o darwinismo social como elemento axial do romance de Rubens Figueiredo, que atualiza a temática da preponderância da ideia do lucro na conformação da sociedade e a violência que daí advém. O autor declara, em entrevista já citada, que os conceitos de evolução e adaptação, propostos por Darwin e acionados em seu romance Passageiro do fim do dia (2010), funcionam como expressão de alguns dos mecanismos que filtram nossa percepção e moldam nossa consciência, a fim de velar a base irracional da sociedade capitalista. Rubens Figueiredo acresce, ainda, que, a despeito de sua discutível validade, são termos em pleno uso no século XXI, largamente repetidos no jornalismo, na economia e áreas correlatas, sempre que relações de dominação estão envolvidas.

A alusão direta ao Humanismo pode ser percebida na explicação que Quincas Borba dá a respeito do nome de sua doutrina "Humanitas": "Assim lhe chamo porque resume o universo, e o universo é o homem" (ASSIS, 2009, p. 58. Grifo nosso). Destarte, o conceito machadiano 
de "Humanitismo" parece parodiar os sistemas filosóficos da época; o positivismo de Auguste Comte e o evolucionismo de Darwin, assim como ironizaria, nas relações humanas encenadas, o jogo de força e poder, a luta por glórias sociais e por prosperidade mundana a qualquer custo.

É possível concluir, portanto, que o ponto mais estreito de bifurcação nas obras dos dois escritores reside em seu questionamento, cada um a seu tempo, da utilização das teorias positivistas, para justificar, ainda hoje, as imensas fissuras sociais. Machado, com indisfarçável descrença, inquire o "homem cordial" de seu tempo, e Rubens Figueiredo procura dar a perceber as engrenagens que movem os menores gestos do cotidiano que, por sua vez, dão continuidade à secular segregação social.

Nesse sentido, importa ressaltar como a organização da obra, mormente do romance, faz circular vozes distintas, colocando-as em diálogo. Nós, por isso mesmo, rastreamos algumas dessas vozes, apontando para o lugar ocupado pelos regentes de tais concertos.

\section{Referências}

ASSIS, Machado de. Quincas Borba. Porto Alegre: L\&PM, 2009. Disponível em: https:// www.lpm.com.br/site/default.asp?Template $=$. ./livros/layout_produto.asp\&CategoriaID =29 2715\&ID=719137. ISBN 978.85.254.0668-2.

ASSIS, Machado de. Memórias Póstumas de Brás Cubas. São Paulo: Egéria, 1978.

BAKHTIN, Mikhail. A pessoa que fala no romance. In: BAKHTIN, Mikhail. Questões de Literatura e de Estética: A Teoria do Romance. Tradução Aurora Fornoni Bernardini et al. São Paulo: Hucitec, 1988.

FIGUEIREDO, Rubens. Passageiro do fim do dia. São Paulo: Companhia das Letras, 2010. ISBN 9788535917604. Disponível em: https://www.companhiadasletras.com.br/detalhe. php?codigo $=13038$.

FIGUEIREDO, Rubens. Entrevista com Rubens Figueiredo. Revista Terceira Margem. Rio de Janeiro, v.15, n.24, p.191-207, jan./jun. 2011. Disponível em: https://revistas.ufrj.br/index. php/tm/article/view/10942. Acesso em: 7 jan. 2020.

FIGUEIREDO, Rubens. Tantas perguntas a Rubens Figueiredo. Entrevista. Revista Usina. 5. ed., abr. 2014. Disponível em: https://revistausina.com/5-edicao/tantas-perguntas-a-rubensfigueiredo/. Acesso em: 7 jan. 2020.

GOMES, Roberto. O alienista: loucura, poder e ciência. In: Tempo Social, v. 5, n. 1/2, p. 145-160. Disponível em: https://www.scielo.br/pdf/ts/v5n1-2/0103-2070-ts-05-02-0145. pdf. Acesso em: 10 jan. 2020.

MACIEL, Luiz Carlos Junqueira. Nada e a nossa condição. In: Cadernos de literatura comentada. Intercampos. N.4. Belo Horizonte; edições Horta Grande Ltda, 2006.

PAIVA, Rejane Debbie Fernández Loureiro de. Subjetividades em trânsito: deslocamentos do 


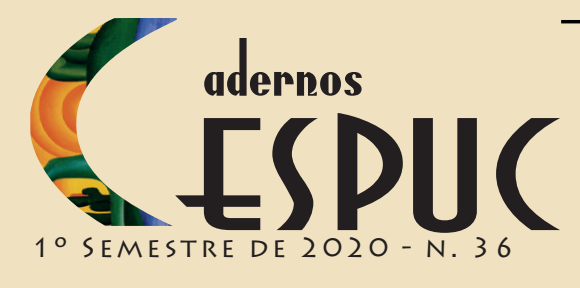

\section{Rejane Fermāndez Loureiro de Paiva}

sujeito em Rubens Figueiredo. 2020. 167 f. Tese (Doutorado em Letras) - Faculdade de Letras da Puc. Pontifícia Universidade Católica de Minas Gerais, Belo Horizonte.

PATROCÍNIO, Paulo Roberto Tonani do. Cidade de lobos: a representação de territórios marginais na obra de Rubens Figueiredo. Belo Horizonte: Editora UFMG, 2016. Disponível em: https://play.google.com/store/books/details?id=n92sDwAAQBAJ.

SILVA, Laila Correa e. A política imperial em Quincas Borba: um diálogo entre a história e a literatura. In: Humanidades em diálogo, v. 8, p. 151-162. Disponível em: https://www. revistas.usp.br/humanidades/article/view/140546. 